The evolution of patent functions: New trends, main challenges and implications for firm strategy

Pascal Corbel, Christian Le Bas

Février 2011 


\section{GATE Groupe d'Analyse et de Théorie Économique Lyon-St Étienne}

93, chemin des Mouilles 69130 Ecully - France

Tel. +33 (0)4 72866060

Fax $+33(0) 472866090$

6, rue Basse des Rives 42023 Saint-Etienne cedex 02 - France

Tel. +33 (0)4 77421960

Fax. $+33(0) 477421950$

Messagerie électronique / Email : gate@gate.cnrs.fr

Téléchargement / Download : http://www.gate.cnrs.fr - Publications / Working Papers 


\title{
The evolution of patent functions: New trends, main challenges and implications for firm strategy
}

\author{
Pascal Corbel \\ University of Versailles Saint-Quentin-en-Yvelines
}

\section{Christian Le Bas}

Université de Lyon, Lyon, F-69003, France ; Université Lyon 2, Lyon, F-69007, France ; CNRS, GATE Lyon St Etienne, Ecully, F-69130, France.

\author{
Corresponding author: Christian Le Bas, ISH- 14, avenue Berthelot, 69363 LYON Cedex 07, France \\ E-mail: christian.lebas@univ-lyon2.fr
}

\begin{abstract}
Recent publications in the field of Intellectual Property (IP) have shown that the previous literature did not grasp how complex patents are. The goal of this paper is to present an overview of all identified functions of patents and of the main strategic implications of such a complex picture. We first survey the main patent functions: innovation protection, functions related to trade and finance, defensive roles, and patent as an input in the innovation process. We then define each function and analyse their main evolution trends in relation with the current environment. We finally identify the strategic implications of each function. We focus on the implications of the newly identified functions and on the interaction between the different functions.
\end{abstract}

Key words

Patent - Intellectual Property - Strategic Management - Functions - Motives to patent

\section{Résumé}

La littérature récente sur les brevets montre combien ils sont complexes. Le but de ce papier esr de fournir un survol des fonctions du brevet et de leurs implications stratégiques. Nous passons en revue les principales fonctions: protection de l'innovation, fonctions relatives à l'échange et à la finance, role défensif du brevet, l'usage du brevet comme input dans le processus d'innovation. Pour chaque fonction nous analysons ses pricipales tendances d'évolution dans le contexte contemporain. In fine, on identifie les implications stratégiques de chaque fonction. On s'intéresse en particulier aux implications des fonctions nouvelles et à leurs interactions.

\section{Mots clés}

Brevet - propriété intellectuelle - management stratégique -fonctions - motivations pour breveter

JEL classification : K4, O31, O34 
Patent management has long been considered as an operational task devoted to experts. Even in the academic world, most publications were concentrated in a small number of journals (Grandstrand, 1999: 89). The reason for this was that the goal of patenting was conceived as simple: a patent confers on its owner exclusive rights. To put it simply, its holder gets a right to exclude other people or organizations from using the bit of new technological knowledge (invention) protected (see for instance Guellec and van Pottelsberghe de la Potterie, 2007). It excludes third parties to manufacture, to use and to sell the invention protected without the permission of the holder (Granstrand, 1999: 71). As a result, in strategic terms, patents are tools to obtain monopoly positions or, more frequently, to protect specific features of a firm's products or processes, and constitute therefore a source of differentiation. But they are not only that.

As Reitzig (2004a: 457) puts it: "Today, the times are over in which economists regarded an individual patent as the guarantee to assure a temporary monopoly position in the market". On one hand, many studies showed that patents had a limited efficacy in playing this role. And, on the other hand, new functions have been taken into account. In other terms, owning patents allows a wide range of conducts. As a result, there has been a growing concern about strategic management of IP, and particularly of patents (Hufker \& Alpert, 1994, Nickerson \& Silverman, 1998, Reitzig, 2004b, Tao et al., 2005). Nevertheless, these papers rarely take into account all the "new" functions of patents. Thus, the goal of this paper is to present an overview of all the identified functions of patents and the main strategic implications of such a complex picture.

The paper is organized as follows. We first analyse the different functions of patents and classify them as innovation protection (part 1), as functions related to trade and finance (part 2), as defensive roles (part 3) and as an input in the innovation process (part 4). In each case, we first define precisely the function, and then describe how it has recently evolved along with the economic, competitive and technological environment. It is indeed necessary to have such a global picture in mind before describing the strategic implications of those functions (part 5). We particularly insist on the implications of the newly identified functions and on the interactions between the different functions (this is why those implications are analysed in a separate part). 


\section{The function of innovation protection: From patent as a right to exclude to a means to secure monopoly position and rents stemming from innovation}

\subsection{Definition}

The first function of patenting (regardless the system of patent) is to protect invention for a temporary period of time (today 20 years maximum). Nevertheless, when applying for a patent, the holder gives the exact picture of the invention he has produced. This information will be diffused all over the world through data sets dedicated to patents. In this respect, patent is a clear opposite to secrecy as a mean for protecting invention. As a consequence there are grounds for imitation or infringement. Without a system of law and of justice, the holder would not be in a position to defend his rights (enforcement issue). An effective system of law and justice is an essential condition to the correct working of a patent system.

This function has been contested by those who think that the capacity of patents to protect is weak in general (Teece, 1998 and 2000). According to them, the patent system cannot alone secure the economic benefits from innovation. Complementary assets are often necessary for protecting the rents stemming from innovation (Teece, 1986). The main complementary assets recognised as effective are: creating superior marketing and after sales service, complexity in the product or the process making it difficult to imitate, or the use of other intellectual property assets such as trademarks or design patents (see below the interaction between IPR assets). The types of complementary assets used will depend on the type of industry and on the relationships with competitors. An efficient firm that masters technological, commercial, economic competencies in the production of innovation that sticks to market needs will patent and invest in specific complementary assets.

The idea has emerged recently in academic research that the patent function of protection differs because of an important factor: the capacity to invent around (we follow here Anand and Khanna, 2000). Let us note that when the knowledge protected is perfectly codified, it is difficult, if not impossible, to invent around. In this case, imitation is not a reliable strategy. Chemical industry is the archetypal example. The system of intellectual property is said "strong". By contrast, the opportunities for imitation are numerous when the parts of knowledge that are protected by patents are less codified, inventing around is feasible (for instance through "reverse engineering" procedures). The system of intellectual property is 
said "weak". Mechanical industries, and more generally the industries in which the technologies are systemic and cumulative are in such a case (Grindley and Teece, 1997). It has some consequences on licensing (see below).

Other systems to encourage $R \& D$ investments, such as prizes or incentives contracts, exist (see the old but always relevant study by Wright, 1983). Depending on whether the value of invention is observable or not, on the quality of information released by private agents and on whether the costs of research can be observed, one system will be better than the other. It has been shown that the patent system is the more effective (and as a consequence preferable) in situations that are more realistic.

This primary protection function corresponds to an economic incentive to invest money in innovative activities (and particularly in R\&D system). In fact the basic idea is the following: at the corporation level, the patent system enables to invest in $R \& D$ projects that would not be profitable otherwise. It gives a premium that has been recently empirically demonstrated by Arora et al. (2002). Price elasticity matters here. When demand is not price elastic the situation is better for the patent holder because the monopoly position does not decrease the demand for the new product. In other terms, customers value more the invention. Finally this incentive function gives rationales for a patent system.

\subsection{Evolution}

Of course, this basic protection function has been preserved until today, but it seems to us that three inflexions have to be recorded in relation with recent trends affecting patenting behaviours.

\section{a. Probabilistic patents}

High-tech industries offer numerous technological opportunities but uncertainty about patent is very high and having patents granted does not offer absolute security. It is the job of intellectual property rights owners to defend their rights against the incursions of other competitors. Due to financial stakes, intellectual property rights may be contested in justice court or infringed. Patents become more and more "probabilistic" (Lemley and Shapiro, 2005). As a consequence a patent gives to its holder rights to try to exclude third parties. Let 
us note that "probabilistic patents" are the acknowledgement of the crucial importance of patent disputes and patent litigation (Lanjouw and Schankerman, 2001) in the new context marked by patent thicket (Galasso and Schankerman, 2008). This trend is stronger in the USA. MacDonald (2004) notes that, often, a clear motive for patenting is to avoid patent litigation suits, not to protect innovations (see part 3).

\section{b. Strategic patents}

In the 1990s, numerous authors have observed a strong increase in patent applications in many countries that stand onto the technological frontier. As at the same time private expenditure on R\&D grew slowly, patent intensity (patent applications per unit of $R \& D$ expenditure) increased significantly (Blind et al. 2006, Jaffe, Lerner 2004; Shapiro 2001). Among the competitive explanation of such a trend, we also consider that patent strategies have changed and have become more complex and comprehensive, leading to an expansion of patent applications (Blind et al., 2006).

Numerous studies (Arundel et al. 1995; Cohen et al., 2002) argue that the patent system is used by companies for various "strategic" motives that aim to protect not particular inventions produced, but the corporation's technological knowledge base as a whole. Therefore patenting is viewed as an instrument for securing the corporation future technological space against competitors or for restricting their future technological opportunities (Blind et al., 2006). Granstrand (1999) lists the various ways for excluding competitors or making competitors' R\&D projects more costly: "blocking patent", "flooding", "mine fields", "fencing" and "surrounding". There is a development/transformation of the traditional patent protection function towards the exclusion of competitors in some technological fields and increasing the market power of the firm. These new motives are sometimes summarised under the general label of "patent blocking". In this respect Arundel and Patel (2003) point out the two ways of the strategic blocking: "offensive" (hampering the technological development of competitors) and "defensive" (protect around the core technological competencies in order to block the attacks from competitors). Strategic patenting tends to deter entry in some technological fields and/or in the industry or a segment of it (Reitzig, 2004).

Some authors observe that this strategic use of patents is in line with the core definition of patents: exclude competitors and a means to maintain a "market" power. 


\section{c. Patent portfolio and patent family}

It has been observed (see among others Granstrand, 1999:223) that firms build up patents portfolios. Patent portfolios serve to scare off new market entrants who rely on the partial systems of other suppliers (Blind et al., 2006). Noel and Schankerman (2006) found that a large patent portfolio enhances the bargaining power of a company. Negotiations about mergers, license contracts, or research co-operations depend upon how the partners evaluate the research efforts of their partners which is often measured in the number of patents in the companies' portfolio (Blind et al., 2006).

Nevertheless there are objective rationales for patent portfolio since in most cases one patent is not enough to protect effectively one invention. Thanks to recent empirical studies on the motives to patent, the links between patent and invention have been extensively investigated. We know that firms apply for more than one patent to protect one invention. The size of the group of patents (sometimes wrongly called patents family ${ }^{1}$, more relevant would be the term of "cluster of patents") protecting the same invention is on average five (Reitzig, 2004). Of course there are variations across technologies and industries. For instance according to Reitzig (2004) in Chemicals, the size of the group of patents is around 8, by contrast in manufacturing machinery, the group is inferior to 5 .

\section{The functions related to trade and finance: patent as an asset.}

As a right to exclude, a patent can secure for the patentee the monopoly rents stemming from the implemented innovation. The right to exclude can be removed by the patent holder who can give the permission to use economically the new bits of knowledge protected by the patent. Patents are increasingly considered as assets aimed at creating value for their holder. A set of functions consequently comes to light, which we labelled functions related to trade and finance. As far as this function is concerned, several aspects have to be pointed out.

\footnotetext{
${ }^{1}$ Patents family in fact is the set of patent granted in different countries protecting the same invention. The size of this "family" is considered as correlated to the value of invention.
} 


\subsection{Definition}

This large function is based on 1) on the traditional exchange procedure of rights through licensing, 2) on the valorisation of patents that increasingly become "quasi financial assets" (Le Bas, 2007).

A license is a permission granted by the holder of the patent to another legal entity (in general an industrial corporation) to make use of it (Granstrand, 1999:414). In this frame there is no cession of rights. The owner (the licensor) stays the owner. The licensee only gets the rights to use the invention. We find in the literature that licensing has given rise to a "market for technology". For many academics this key function marks the superiority of the patent system as a means to diffuse new technological knowledge. Other means for protecting innovation do not permit the exchange of new knowledge as does the patent system with security for the traders. Moreover it has been emphasized that licensing providing more value for the licensor (that is very often an industrial firm) contributes to increase the incentives to invest in $R \& D$ (Gallini and Winter, 1985).

This type of transaction is more complex than the exchange of industrial goods (Teece, 1998 and 2000). Generally, in addition to licensing properly speaking, the owner sells other services as transfer of knowledge and how-how. This transfer of tacit knowledge is crucial for the effectiveness of licensing processes and to create the conditions of trust between partners (Arora, 1995). Moreover, several authors pointed out the imperfections of the market for technology in particular the opportunistic behaviour of the licensee (sell to third-parties the bits of knowledge protected by the patent) and the risks incurred by the licensor (Teece, 1998 and 2000).

As strongly noted by Anand and Khanna (2000) the type of intellectual property system (strong or weak) matters. When imitation is not really possible or when it is easy to show that it matches an infringement, licensing out is a reliable strategy. We observe that in industries such as Chemicals or Pharmaceuticals that the number of contracts is high. By contrast, when the opportunities to imitate or invent around are numerous (in the case of a "weak" system of intellectual property), licensing is often too risky for the patent holder. We observed this for instance in Mechanical industries where the volume of licensing is weak. 
As an acknowledged security, a patent must be assessed in the corporation balance sheets. It may be transferred, sold, etc. As IP has become increasingly recognised as a legally and valuable transferable asset class, numerous creative strategies have emerged to generate cash, minimise taxes and raise capital.

\subsection{Evolution}

\section{a. Bargaining and strategic role of licensing}

In recent years, we observe a real upsurge in licensing. The market for technology has undergone an unprecedented rapid expansion (see the book by Arora. et al., 2001). But the trade aspect of patent is more marked with the upsurge of cross-licensing. According to Granstrand (1999: 414) licenses are swapped between licensors and licensees. In other terms, they exchange rights to exclude themselves. In some sectors (semiconductors are amongst the most emblematic), bundles of hundred patents are cross-licensed (see Hall and Zeidonis, 2001). It enables to avoid that the patents of the competitors block the development of R\&D programs. This function is further developed in section 3.

Conventional wisdom (that we find in text books) suggests that patenting tends to create competitive advantages. This creates a dilemma between value creation through differentiation and direct revenues from licences (Fosfuri, 2006). Nevertheless, a growing number of corporations value their core intellectual property assets and seek to license them to their competitors. This appears in industries in which patents are related to standards. For instance Motorola licensed its GSM standard technology to Nokia and Ericsson in 2001, which generated a significant recurring royalty stream. It also provided a long-term strategic benefit by helping to direct industry R\&D to an area best suited to the company's position and strategy (see Intellectual Asset Management April/May 2007). 


\section{b. Patent as a quasi financial asset: Development of new practices}

Over recent years, a number of ways to turn patents (and more generally IP rights) into money have become increasingly popular: emergence of (public and private ${ }^{2}$ ) auctions, direct sales and online patents exchanges have broadened rights owners' options considerably (see Wild, $\left.2009^{3}\right)$.

In the new context, patent litigation has become a concern of paramount importance in financial markets. It appears that there has been a significant increase in the number of company stock price moves being attributed to IP litigation events at the New York Stock Exchange.

As noted by authors from "Intellectual Asset Management" Journal, things are beginning to change as experts in the financial community become more conscious of the IP potential. It first came to light with the so-called Bowie Bonds and other securitisations, while now all types of products are available: collateralisation, sale and leaseback and bank debt. For IP owners, the range of options is greater than it has ever been before.

Patents have become important assets to improve access to capital markets, especially but not only for start-up companies (Blind et al., 2006). Coriat and Orsi (2002) show that a synergy exists (giving rise to institutional complementarities) in the biotech sector between the patent system that effectively protects the most valuable inventions and financial markets that need actual trust produced by the patent system.

Some new practices are equally located at the first stages of the innovation process, in particular the "Incubating Fund", which acquires patented technologies, invests in incubation and commercialises them at a later stage.

These new mechanisms (directed towards IP financing whatever the forms they can take) go beyond the new set of private (venture capital) and public (epitomized by the NASDAQ in the

\footnotetext{
${ }^{2}$ For valuable IP, strategic private auctions are the best mechanism for realising value while avoiding the pitfalls of open public auctions. A strategic private auction process requires more sell side valuation and due diligence activities, including targeting the right mix of bidders and tailoring the value proposition to each bidder (see Intellectual Asset Management April/May 2007).

${ }^{3}$ He added; "This is without considering the benefits of tax-efficient IP planning and the possibilities presented by strategic M\&A".
} 
US) capital markets for "technology strategy companies". By supporting such companies and enabling returns anticipation, these institutions promote the creation in industrial leading economies of a specialized segment of 'inventor' companies. Such markets are specialized in knowledge intensive property rights (Antonelli and Teubal, 2009).

\section{c. Tax optimisation}

A corporation is expected to minimise its overall tax rate. For example, a patent litigation settlement may be structured as a sale to receive favourable capital gains treatment, but this structure makes sense only if the patent owner has no further strategic interest in the patent. Internationalised large firms with a centralised and integrated management of company's intellectual property can organise intercompany licensing arrangements that minimise taxation (most countries have a favourable taxing regime for licensing fee in order to attract R\&D activities).

\section{The defensive roles of patent}

As we mentioned briefly before, some companies do not patent only to seek protection or licensing revenue but also to minimize the risk to be sued for patent infringement. The goal and it can be the main goal of some firms - is to preserve its freedom to operate.

\subsection{Definition}

The aim is not to gain competitive advantage directly from patents, but to prevent competitors to threat another source of competitive advantage through legal action. Although sometimes mentioned, this role has long been somewhat neglected in the literature. But it has undergone a growing interest since the end of the 1990s.

Patenting contributes to preserve the firm's freedom to operate through three functions:

- The simplest is the fact that patenting an invention prevents the competitors to patent the same invention. In other terms, it reduces the scope of future patents in the same technological area. This role often appears in the literature as "defensive blockade" (Blind et al., 2006). 
- The second is that the portfolio of patents of a firm can be used as a means of exchange in the case of a litigation threat. It allows a firm that has been notified that they infringe another firm's patents to propose a cross-licensing agreement. "Patents become a "currency" in the market for technological modules and knowledge" (Blind et al., 2006:658).

- The third can be described as a "deterrence" role although the term is rarely used in the literature (Granstrand, 2000:1067 used "retaliation power"). It is more risky to sue a competitor that owns a large patent portfolio because it can use it to replicate. This can explain an interesting statistical negative relation discovered by Lanjouw and Schankerman (2001) between the number of patents owned and the probability to be involved in a patent suit.

\section{2. $\quad$ Recent evolutions}

The defensive roles of patents are especially important in the semiconductor and electronics industry (Grindley and Teece, 1997 ; Hall and Ziedonis, 2001). The reason is that producing electronic products implies multiple technologies generally patented by several firms. In other terms, the defensive roles are important when complex technologies are involved (Reitzig, 2004).

As a result, preserving one's freedom to operate can be inferred to be a growing motive to patent. Indeed, the number of patent applications has increased at a very high pace in this industry during the 1990s, explaining part of the so-called "patent surge" (Kortum and Lerner, 1999). Moreover, there seems to be a trend towards more and more complexity in previously discrete technologies. For example, the pharmaceutical industry is the archetype of a discrete technology sector. But the emergence of new biotechnologies and especially genomics involves a growing use of computer science and complex diagnosis systems.

Nevertheless, it is difficult to confirm such a trend as the studies on motives to patent define them in different ways (for a synthesis, see Blind et al., 2006). Moreover, the scope of these studies is generally one or two countries while differences are important between countries (Cohen et al., 2002). It is therefore difficult to measure precisely the evolution of the relative importance of the main motives to patents. 


\section{The patent as an input in the innovation process}

\subsection{Definition}

Patents are outputs of the innovation process. But they are not only outputs. Of course, they are incentives to innovate. But, they are also incentives to disclose technological information. As innovation is cumulative, patents are also used as a basis for further developments. As stated by Mazzoleni and Nelson (1998:277-278) : "It is clear that many patents are granted quite early in the innovation process, with a lot of follow on work needing to be done before the crude invention is ready for actual use." The use of patent databases as a source of technological knowledge is very different from a firm to another, and from a country to another (for instance the Japanese firms seem to use them more than most of their occidental counterparts, see Granstrand, 1999 and Pitkethly, 2001).

Patents also facilitate R\&D cooperation. First, it makes it easier to find partners. Patents have a « signaling » function (Pénin, 2005). Owning patents in a technological field is a signal that the firm is competent in that field. It is also easier to compare the patent portfolio of firms than their tacit knowledge to evaluate their background. Second, patents give multiple options to share the results of the partnership (the foreground): shared property, licenses with various possibilities (Brouwer and Kleinknecht, 1999, Arundel, 2001).

Finally, patents are also potential incentives for R\&D employees and an internal performance indicator. Blind et al. (2006) found that, although they have under-average significance, $22 \%$ (indicator performance) to $32 \%$ (incentives for employees) of interviewed managers in German firms consider them as "important" or "very important" motives to patent.

\subsection{Recent evolutions}

Recently, computerized tools have been developed to facilitate technological analysis through patent databases (Granstrand, 1999, Rivette and Kline, 2000). Access to patent databases via Internet also facilitates the use of patents as inputs in the innovation process. But the main reason why this role becomes more and more important lies in the structure of the innovation process. 
The innovation process was initially viewed as the initiative of an isolated entrepreneur (Schumpeter, 1912). Then, the dominant approach was the internalized R\&D department inside a large firm (Schumpeter, 1947). But some authors argue that a new paradigm has been emerging for the last decades: an open innovation model (Chesbrough, 2003) which combines entrepreneurial innovation (in small firms, especially start-ups) and R\&D department innovation.

In such environments, big firms scan their technological environment to find partners or to gain technological competencies through start-up acquisition. Then, they develop and commercialize those inventions. Such an open-innovation process gives a central role to IPRs and especially to patents:

- They are one of the tools used to scan the environment to find the relevant partners and/or acquisition targets (although of course not the only ones: scientific publications may play a similar role in science-based industries, and, above all, informal relations are very important to find that kind of information).

- They provide a way for start-ups (and more and more universities) to gain a profit from their initial innovation through licensing.

As a result, patents are particularly important for start-ups. They have limited ways to signal their competences in a field. Their patent portfolio is one of the most important (Niosi, 2003). This is crucial during the first steps of the innovation process because they need both to raise funds and to get into innovation networks (Powell et al., 1996). It is also important to push the innovation process further when they do not own the necessary complementary assets to take profit from their innovation. Patent is a crucial element of the "symbiotic coexistence" (Rothaermel, 2001) between large firms (e.g. "big pharmas") and start-ups (e.g. biotechs).

\section{Implications for strategic management}

The four first parts of this paper have showed that patents can be used for various purposes, and not only to protect an innovation. The weight of these different functions varies according to national factors (according to patent law and the way it is applied), to industry factors (especially according to the type of technology used, discrete or complex, Reitzig, 2004a), and to factors specific to firms (its size being one of the most influential). But it should also 
vary according to the main strategic objectives of a firm. The aim of this part is to present the main strategic implications of the variety of patent functions.

We first show how the functions related to trade and finance, and the way patents can be used as an input in the innovation process can help to face a more complex strategic environment (a). It leads us to identify how patents can be used in the management of the relations with other firms, especially potential partners and competitors (b). We then analyze how this can be taken into account in resource allocation and budgeting (c). Finally, we insist on the interactions between the different functions (d), which is a point rarely analyzed in the literature.

\section{a. The new role of markets for technology and the increasing strategic space}

It has been noted that patenting can influence the location of technological innovation and affect the firm boundaries in an effective way. It is in a sense another function of patenting. Arora and Merges (2004) propose a simple model supported by empirical case studies in which the basic choice is whether a technology-intensive input will be supplied by an independent firm or it will be produced in-house. They analyze how the choice is affected on the one hand by the strength of intellectual property rights and by the existence of information spillovers on the other. They show that when the supply relationship is likely to produce new information of value to the supplier, stronger property rights favour independent suppliers over vertical integration. As pointed out by the authors, strong patent systems encourage investments in specialized firms with firm capabilities in the area of innovative input supply (see also Antonelli, 2008). Diana Hicks and Deepak Hedge (2005) bring another piece to this analysis. They give empirical evidence that in some cases the viability of small specialized firms is large. Their superior ability to innovate is persistent and they may become serial innovators. The role of patenting is in this new trend of division of innovative labour ("That market in which transactions create technologies") is testified.

Arora A. et al., (2001) have strongly emphasized the fact that the surge of markets for technology (included the licensing but also all type of transaction on IP assets) has important implications for firms (presumably large): it increases the strategy space. Firms can choose to develop in-house or license out, to buy technologies or license in, and so on. It requests a pro 
active management of intellectual property that has a pivotal role in the building and the maintaining of firm competitive advantages.

For instance, IP management becomes one of the core strategic capabilities in the open innovation paradigm (Chesbrough, 2006). One of the basic tensions of strategic management is to exploit existing core competencies (Prahalad and Hamel, 1990) while simultaneously enlarging the portfolio of those competencies by acquiring new ones and exploring new ways (March, 1991). The rise of markets for technology facilitates the management of this tension:

- Some knowledge can be acquired directly through those markets. Codified knowledge is rarely sufficient to permit an efficient use of a technology, but licensing in, combined with the development of absorptive capabilities (Cohen and Levinthal, 1990) can speed up access to missing technologies.

- IP also become an important tool to implement R\&D partnerships, especially through the "signalling" function.

Such an easier access to outside complementary competencies can be used in order to proactively enlarge the strategic scope of the firm (by combining its existing competencies with new ones) or to adapt to changes in the environment such as industry merging (e.g. IT and telecommunications).

- New options emerge when new pieces of technological knowledge are created inside the firm. The use of IP is often necessary when new knowledge is used in new products whether to protect it from imitation from competitors or to diffuse the technology among them to push a new standard (Shapiro and Varian, 1998).

The traditional "go or no go" decision in R\&D project management can therefore be enriched with intermediary choices such as exploit it outside the firm (licensing out) or at its frontier (spin-offs).

\section{b. IP as a relation management tool}

Being able to build relationships with relevant partners is now recognized as a potential source of competitive advantage (Dyer and Singh, 1998). As innovation becomes increasingly important in many industries, it includes the ability to get into networks of innovation (Powell et al., 1996). From this point of view, patent is both a way to signal its competence in a technological field, to detect the more relevant partner(s), and to negotiate a balanced partnership. It has some implications for the management of patents. The firm may apply for 
patents sooner (signaling function) and apply for other patents when improvements to the original invention are made (signaling function, assets for partnership negotiations). It has also more incentives to develop a "patent culture" (Granstrand, 1999: 264-627). From a managerial point of view, it means:

- Top management involvement in patenting and IP.

- Patenting and IP as a common concern for all engineers.

- Patent policies and strategies integrated in business plans.

- Clear patent objectives.

- Clear patent incentives for R\&D personnel and organizational units.

- Fostering of behavioural attitudes and norms.

- Visible organizational means such as patent liaison officers.

- The development of a common language and concepts about patents and IP.

A widespread knowledge on patents should logically lead to more patent applications but also to a wider use of patents as sources of information. As a result, it is a practical means to strengthen the firm absorptive capabilities (Cohen and Levinthal, 1990).

The concept of absorptive capabilities leads us to insist on one of the implications of such a widened view of patent. There is a natural tendency to separate the internal R\&D activity and the ability to import knowledge and ideas from outside the firm. But Cohen and Levinthal (1990) found that the two were strongly linked. This leads us to see the various uses of IP as a system in which functions linked to internal activities (protection from imitation, licensing out, incentives for R\&D personnel...) are intertwined with functions linked to external relations (technological environment scanning, licensing in...). Indeed, some of the roles that we study in this article are at the frontier between the two (cross-licensing, deterrence). 


\section{c. Managing portfolios rather than individual patents}

The importance of patent portfolio management has been underlined in some previous works. As shown in part 1, individual patents are effective as protection tools only in some specific industries such as chemicals and pharmaceuticals. In most cases, firms need to build patent clusters. Granstrand (1999: 218-222) has described tactics that use multiple patents to augment the protection.

Rivette and Kline (2000) focus on another important point of patent portfolio management: systematic portfolio reviewing. Portfolio reviews have two goals. The first is to reduce cost by abandoning patents that have no use. It is nevertheless important in such cases to take into account all the functions that we identified. A patent can be useful even if it does not protect effectively an innovation and brings no licensing fees. For example, it can be used for offensive blockade or as a means of exchange in cross-licensing agreements. The second goal is to detect potential underused patents. Rivette and Kline (2000) give some examples of companies such as IBM that developed rapidly their licensing income essentially by implementing an active patent portfolio management. But portfolio management is not only influenced by offensive functions.

As we mentioned in part 3, the size of the porfolio is important for both deterrence and crosslicensing. This is true in an absolute sense, especially as far as the retaliation power effect is concerned. What is important here is that the portfolio is so large that it is (almost) impossible for a competitor to make sure that it does not infringe any of the patents. But it is also true in a relative way when patents are used as a currency in cross-licensing agreement. The result is a strong incitation to apply for a large number of patents, which can partly explain the rise of patent application in the 1990s (Hall and Ziedonis, 2001). It can also explain that "forced to patent because of patent practice of others" appeared as the most important motive to patent in a 2003 OECD study (Blind et al., 2006). As a result, the fact that patents are also used to preserve a firm's freedom to operate makes the inclusion of this "portfolio effect" particularly important. In technological fields, where it is impossible to analyze each patent one by one because of their number, the size of the portfolio becomes very important. It is risky to sue a competitor that has a large portfolio as there is a high probability that a counter-suit is possible. In a study on patent litigation and settlement, Somaya (2003) found that when there was a counter-suit, the suit and the counter-suit where almost always disposed within a day of 
each other: it shows that the original suit triggered the counter-attack. Moreover, global crosslicensing agreements are often used to prevent litigation in complex technologies industries (Grindley and Teece, 1997), and the size of the portfolio is one of the main determinants of the assessed value of each of the party (hundreds or even thousands of patents are concerned so that it is impossible to evaluate the value of each of them).

This raises an interesting paradox. Massive patenting that aims to preserve freedom to operate paradoxically also raises barriers to entry. In that case, patent portfolios play the same role as R\&D alliances in biotechnology startups: it is an "admission ticket" (Powell et al., 1996). Firms that do not own a significant patent portfolio cannot access the incumbents' technologies, and therefore cannot enter the market. As Lemley and Shapiro (2005:82) put it: "One way to cut through the patent thicket is for incumbents with extensive patent portfolios to enter into broad cross-licenses (that is, exchanges of roughly symmetric patent positions) to "clear" the thicket. However, new entrants who lack large patent portfolios may be at a major disadvantage in this situation because they have no patents to trade." In that case, patents favor more oligopolies than monopolies. Nevertheless, high-tech start-ups willing to enter such a market can apply for key patents that would give them this "admission ticket". It encourages start-ups to apply for patents early in their life (Corbel, 2005).

\section{d. The interactions between the functions}

Each of the potential roles of patents leads to different strategies. The main decisions concern patent applications, international extension (family size), life duration and litigation. When patents are used mainly for offensive purposes (exclusion, licensing out), firms have to apply for a basic patent, with a large scope, but also for many dependent patents to protect the original invention from design around. The main patents have to be extended to all the key markets of the firm, and they are maintained as long as the technology is not obsolete. Any counterfeiting leads to litigation, even if in most cases the suit is settled before going to court (Somaya, 2003). When defensive functions are more important, the number of patent applications remains high, but family size can be smaller and patent life shorter, especially when the goal is to limit the patent scope of competitors (a patent in a single country prevents competitors to obtain a patent for the same invention anywhere in the world). When building a patent culture or motivating $R \& D$ employees are important goals, the number of patent applications should also be high (so that as many employees as possible are concerned). 
Whether international extension is important or not depends on the quality of the national patent system (e.g. obtaining a patent in France is considered as quite easy, so that obtaining a European patent will valorize the inventor much more). The duration of patents is less important. This is also the case when "technological image" is an important motive to patent.

It would be interesting for scholars to study how those choices are made. Few studies focus on the process of decision in the field of IP. If the behavior of firms is considered as rational, the part of patents extended to other countries, the number of countries where patents are extended ${ }^{4}$ and the average life duration could even be used as proxy measures for the relative weight of offensive and defensive functions in the strategy of a firm. A study on how deterrence effect works in practice would also be interesting. It is sometimes mentioned (e.g. Pénin, 2005). Lanjouw and Schankerman (2001) have shown that a statistical relation exists between the size of the patent portfolio and the probability to be involved in a patent suit. But, to our knowledge, no in-depth study of this phenomenon has been published so far although it seems to be important for professionals (Hagel, 2005).

As a result, we can say that there is a trade-off between the various roles of patents, some of them being complementary or "synergistic" but other being competitors for the same resources. For a given budget, a firm will have to favor some functions to the detriment of others. It is therefore very important for IP managers to determine a hierarchy of those functions in relation with the firm strategy.

\section{Conclusion}

Rivette and Kline (2000) give numerous examples of firms that increased the gains (especially, but not only, licensing revenues) from their patent portfolio only by implementing better management systems. Our review of the multiple roles of patents shows that (good) patent management consists in combining multiple competences from different fields (technology, law, but also strategic management). Despite some interesting descriptions of Japanese firms IP management by Granstrand (1999), the way firms combine those different resources and competences in order to obtain a sustainable competitive advantage has not

\footnotetext{
${ }^{4}$ Harhoff et al. (2003) have found that family sizes were globally larger in chemical and pharmaceutical industries, and that this variable was better correlated with patent value than in other industries. This can be related to the fact that the "protection from imitation" role is predominant in these industries.
} 
been studied in depth yet. We argue that it can be an interesting conceptual framework to guide future studies.

Patent management is implicitly considered in the literature as an operational task. The work is supposed to be done by specialized departments inside firms and patent lawyers / consultants outside. The only managerial variable taken into account is the value of the protected innovation that leads to different decisions in terms of renewal and family size (Harhoff et al., 2003) or litigation (Somaya, 2003). As a result very few studies focus on the way IP management is organized (see Granstrand, 1999 or Ayerbe and Mitkova, 2008, for exceptions). Our review of the multiple functions of patents, their evolutions and their interactions shows that patenting decisions are complex in essence and that patent strategy consists in fine tuning between various goals. Some of them reinforce each others while others are in competition for scarce resources (financial resources but also human resources). With such a complex picture in mind, the strategic management of patents becomes a much more interesting field of study.

The hierarchy of patent functions has to be related to the strategy of the firm. We argue that the term "strategic patenting" is misused in the economic literature where it covers the objectives beside the traditional protection purpose (Blind et al., 2006:656). "Strategic patenting" is the use of patents to support business (and more rarely corporate) strategy. Opting for such a definition opens the way to the use of some strategic management concepts rarely associated to patents. Patents are obviously a resource in the sense of the ResourceBased View (Hall, 1992). Patents are valuable as they cover a specific invention. But they respect the VRIN conditions (Barney, 1991) ${ }^{5}$ only in rare cases. They are non-imitable resources only when inventing around is not possible. So, the relations between patents and sustainable competitive advantage might be more indirect. It may be more related to the way patents are managed than in the patents themselves.

We really think that only a good assessment of the evolution of patent functions may drive to a better view of strategic implications of patenting.

\footnotetext{
${ }^{5}$ According to him, a resource can be a source of sustainable competitive advantage only if it is valuable (V), rare (R), difficult to imitate (I) and has no substitute (N).
} 


\section{References}

Anand, B.N. \& Khanna, T. (2000) "The structure of licensing contracts”, The Journal of Industrial Economics, Vol. XL VIII, 103-135.

Antonelli C. (2008) Localised Technological Change. Towards the Economics of complexity, Routledge.

Antonelli C. \& Teubal M. (2009) "Venture Capitalism, New Markets and Innovation-led Economic Growth", ICER Working Paper, No 03/2009.

Arora A. (1995) "Licensing Tacit Knowledge: intellectual property rights and the market for Know-How", Economics of Innovation and New technology, Vol.4, 41-59.

Arora A. \& Merges R. P. (2004) "Specialized supply firms, property rights and firm boundaries", Industrial and Corporate Change, Vol.13, No 3, 451-475.

Arora A. et al. (2001) Markets for Technology and their implications for Corporate Strategy. Industrial and Corporate Change, Vol.10, No 2, 419-450.

Arundel A. (2001) "The Relative Effectiveness of Patents and Secrecy for Appropriation", Research Policy, Vol.30, 611-624.

Arundel A., Van de Paal G. \& Soete L. (1995) Innovation Strategies of Europe's Largest Industrial Firms, PACE Report, MERIT, University of Limbourg, Maastricht.

Arundel A. \& Patel P., (2003) "Strategic patenting", Background report for the Trend Chart Policy Benchmarking Workshop: New Trends in IPR Policy, Luxembourg, June.

Ayerbe, C. \& Mitkova, L. (2008) «Stratégies de brevet et arrangements organisationnels au sein des grands groupes industriels français », Management International, Vol.12, No 4, 1124.

Barney, J.B. (1991) "Firm resources and sustained competitive advantage", Journal of Management, Vol.17, 99-120.

Blind, K., Edler, J., Frietsch, R. \& Schmoch, U. (2006) "Motives to patent: Empirical evidence from Germany", Research Policy, Vol.35, 655-672.

Brouwer E. \& Kleinknecht A. (1999) “Innovative Output, and a Firm's Propensity to Patent. An Exploration of CIS Micro Data", Research Policy, Vol.28, 615-624. 
Chandler, A.D. (1962) Strategy and Structure: Chapters in the History of the American Industrial Enterprise, MIT Press.

Chesbrough, H. (2003) “The Era of Open Innovation”, MIT Sloan Management Review, Spring, 35-41.

Chesbrough, H. (2006) "Open Innovation: A New Paradigm for Understanding Industrial Innovation" in Chesbrough, H. ; Vanhaverbeke, W. \& West, J., Open Innovation: Researching a New Paradigm, Oxford University Press, 1-12.

Cohen, W. M. \& Levinthal, D.A. (1990) “Absorptive Capacity: A New Perspective on Learning and Innovation", Administrative Science Quarterly, Vol.35, 128-152.

Cohen, W.M., Goto, A., Nagata, A., Nelson, R.R. \& Walsh, J.P. (2002) "R\&D spillovers, patents and the incentives to innovate in Japan and the United States", Research Policy, Vol.31, 1349-1367.

Corbel, P. (2005) « Le brevet : un outil de coopération/exclusion» in Bensebaa, F. \& Le Goff, J., Stratégies concurrentielles - Le renouveau théorique en pratique, Caen, EMS, 23-47.

Coriat B. \& Orsi F. (2002) "Establishing a new intellectual property rights regime in the United States. Origins, content and problems”, Research Policy, Vol.31, 1491-1507.

Dyer, J.H. \& Singh, H. (1998) “The Relational View: Cooperative Strategy and Sources of Interorganizational Competitive Advantage", Academy of Management Review, Vol.23, No 4, 660-679.

Galasso A. \& Schankerman M. (2008) "Patent Thickets and the Market for Innovation: Evidence from Settlement of Patent Disputes", CEPR Discussion Papers, No 6946.

Gallini N. \& Winter R. A., (1985) « Licensing in the Theory of Innovation », Rand Journal of Economics, Vol.16, No 2, 237-252.

Granstrand, O. (1999) The Economics and Management of Intellectual Property, Edward Elgar, Cheltenham, Northampton.

Grindley, P.C. \& Teece, D.J. (1997) "Managing Intellectual Capital: Licensing and CrossLicensing in Semiconductors and Electronics", California Management Review, Vol.39, No $2,8-41$.

Guellec D. \& van Pottelsbergh de la Potterie, B. (2007), The Economics of the European patent system, Oxford University Press. 
Fosfuri, A. (2006) "The licensing dilemma: understanding the determinants of the rate of technology licensing”, Strategic Management Journal, Vol.27, 1141-1158.

Hagel F. (2005) “Both sides - How Valuable are Patents to Companies?”, Patent World, No $176,14-17$.

Hall, R. (1992) “The Strategic Analysis of Intangible Resources”, Strategic Management Journal, Vol.13, 135-144.

Hall, B. \& Ziedonis, R.H. (2001) "The Patent Paradox Revisited: an Empirical Study of Patenting in the U.S. Semiconductor Industry, 1979-1995", RAND Journal of Economics, Vol.32, No 1, 101-128.

Harhoff, D., Scherer, F.M. \& Vopel, K. (2003) "Citations, family size, opposition and the value of patent rights", Research Policy, Vol.32, 1343-1363.

Hicks D. \& Deepak Hegde D. (2005) "Highly innovative small firms in the markets for technology", Research Policy, Vol. 34, No 5, 703-716.

Hufker, T. \& Alpert, F. (1994) "Patents: A Managerial Perspective", Journal of Product \& Brand Management, Vol.3, No 4, 44-54.

Intellectual Asset Management (2007): Wild J., “IP finance and monetisation”, IAM Management report.

Jaffe A. \& Lerner J. (2004), Innovation and Its Discontents: How Our Broken Patent System is Endangering Innovation and Progress, and What to Do About It, Princetown University.

Kortum, S. \& Lerner, J. (1999) "What is behind the recent surge in patenting?", Research Policy, Vol.28, 1-22.

Lanjouw, J.O. \& Schankerman, M. (2001) "Enforcing patent rights", NBER working paper, No 8656.

Le Bas C. (2007) Économie et Management du brevet. Le système de brevet dans l'économie contemporaine, Économica, Paris.

Lemley, M.A. \& Shapiro, C. (2005) "Probabilistic Patents", Journal of Economic Perspectives, Vol.19, No 2, 75-98.

MacDonald S. (2004), « When means become ends: Considering the impact of patent strategy on innovation », Information Economics and Policy, Vol. 16, No 1, 135-158. 
March, J.G. (1991) "Exploration and Exploitation in Organizational Learning”, Organization Science, Vol.2, 71-87.

Mazzoleni, R. \& Nelson, R. (1998) “The Benefits and Costs of Strong Patent Protection: A Contribution to the Current Debate", Research Policy, Vol.27, 273-284.

Nickerson, J.A. \& Silverman, B.S. (1998) "Intellectual Capital Management Strategy: The Foundation of Successful New Business Generation”, Journal of Knowledge Management, Vol.1, No 4, 320-331.

Niosi, J. (2003) “Alliances are not enough explaining rapid growth in biotechnology firms", Research Policy, Vol.32, 737-750.

Noel M. \& Schankerman M. (2006) "Strategic Patenting and Software Innovation”, CEPR Discussion Paper, No 5701.

Pénin, J. (2005) "Patents versus ex-post rewards: A new look", Research Policy, Vol.34, 641656.

Pitkethly, R.H. (2001) "Intellectual property strategy in Japanese and UK companies: patent licensing decisions and learning opportunities”, Research Policy, Vol.30, 425-442.

Powell, W.W., Koput, K.W. \& Smith-Doerr, L. (1996) “Interorganizational Collaboration and the Locus of Innovation: Networks of Learning in Biotechnology”, Administrative Science Quarterly, Vol.41, 116-145.

Prahalad, C.K. \& Hamel, G. (1990) "The Core Competence of the Corporation", Harvard Business Review, No 3, 79-91.

Reitzig, M. (2004a) “The Private Values of 'Thickets' and 'Fences': Towards an updated Picture of the Use of Patents across Industries”, Econ. Innov. New Techn., Vol.13, No 5, 457476.

Reitzig, M. (2004b) "Strategic Management of Intellectual Property", MIT Sloan Management Review, Spring, 35-40.

Rivette, K.G. \& Kline, D. (2000) Rembrandts in the Attic, Harvard Business School Press, Boston.

Rothaermel, F.T. (2001) "Complementary assets, strategic alliances, and the incumbent's advantage: An empirical study of industry and firm effects in the biopharmaceutical industry", Research Policy, Vol.30, 1235-1251. 
Schumpeter, J.A. (1912), Théorie der wirtschaflichen Entwicklung, Veränderte Auflage, Dunker und Humblot.

Schumpeter, J.A. (1947), Capitalism, Socialism and Democracy, Gerogre Allen and Unwin, London.

Shapiro C. (2001) "Navigating the Patent Thicket: Cross Licences, Patents Pools, and Standard-Setting", Innovation Policy and the Economy, Vol. 1, 119-150.

Shapiro, C. \& Varian H.R. (1998) Information Rules. A Strategic Guide to the Network Economy, Harvard Business School Press.

Somaya, D. (2003) "Strategic determinants of decisions not to settle patent litigation", Strategic Management Journal, Vol.24, No 1, 17-38.

Tao, J.; Daniele, J.; Hummel, E. ; Goldheim, D. \& Slowinski, G. (2005) "Developing an Effective Strategy for Managing Intellectual Assets", Research Technology Management, January-February, 50-58

Teece, D.J. (1986) "Profiting from technological innovation", Research Policy, Vol.15, No 6, 285-305.

Teece D. J. (1998) "Capturing value from knowledge assets: The new Economy, markets for know-how, and intangible assets", California Management Review, Vol.14, No 3, 55-79.

Teece D. J. (2000) Managing Intellectual Capital. Organizational, Strategic and Policy Dimensions, Oxford University Press.

Teece, D.J., Pisano, G. \& Shuen, A. (1997) "Dynamic Capabilities and Strategic Management", Strategic Management Journal, Vol.18, No 7, 509-533.

Trajtenberg, M. (1990) “A penny for your quotes: patent citations and the value of innovations", RAND Journal of Economics, Vol.21, No 1, 172-187.

Wright B. (1983) "The Economics of Invention Incentives: Patents, Prizes, and Incentives Contracts", American Economic Review, Vol.73, 691-707. 